\title{
10. PLIOCENE AND PLEISTOCENE BIOSTRATIGRAPHY OF BACHMAYERELLA TENUIS AND INCERTAE SEDIS, FORMA A, EASTERN MEDITERRANEAN, HOLES 965A, 966A, 967A, AND 969A ${ }^{1}$
}

\author{
Silvia Spezzaferri ${ }^{2}$ and Dorothee Spiegler ${ }^{3}$
}

\begin{abstract}
The range of Bachmayerella tenuis and Incertae sedis, forma A, allows a remarkable improvement of the stratigraphic resolution of the Pleistocene interval spanning the Globigerina cariacoensis and Truncorotalia truncatulinoides excelsa Zones. Bachmayerella tenuis last occurs in the lower part of the calcareous nannofossil Zone NMNN19a. Incertae sedis, forma A, last occurs in the lower part of Zone MNN19f. An informal zonation incorporating planktonic foraminifer bioevents and the last occurrence (LO) of these two forms, probably belonging to the calcdinocyst group, is proposed as follows: Subzone A (Bachmayerella tenuis) spans the interval from the increasing abundance of $N$. pachyderma sinistral to the $\mathrm{LO}$ of $B$. tenuis. Subzone B (Incertae sedis, forma A) spans the interval from the LO of Bachmayerella tenuis and the LO of the Incertae sedis, forma A. Subzone C (T. truncatulinoides excelsa) spans the interval from the LO of the Incertae sedis, forma A, and the modern seafloor.

The new form, Incertae sedis, forma A, is informally described. The isotopic composition of the Incertae sedis, forma A, tests is similar to the isotopic composition of the benthic foraminifer Oridorsalis stellatus. Further studies, including a light optical investigation on the wall texture, are currently underway to clarify its taxonomic position.
\end{abstract}

\section{INTRODUCTION}

Dinoflagellates are monocellular organisms belonging to the marine phytoplankton. During their life cycle, these organisms may have a "resting stage" and produce benthic cysts, which allow for survival during time periods when physical or chemical conditions of the planktonic habitat are beyond the physiological tolerance of the vegetative cells (Dale, 1983; Sandgren, 1983). When the cysts are composed by silica or carbonate (calcdinocysts), they can be fossilized. These cysts are very common in both Mesozoic and Cenozoic sediments (Keupp, 1990; Hildebrand-Habel and Willems, 1996).

During Ocean Drilling Program (ODP) Leg 160, 11 sites (Sites 963-973) were drilled in the Eastern Mediterranean (Fig. 1). These holes display rather extended and continuous sedimentary sequences spanning the Pliocene-Pleistocene interval. Table 1 shows geographic coordinates, water depth, and penetration at each hole. Bachmayerella tenuis and Incertae sedis, forma A, a problematic microfossil that possibly belongs to the calcdinocysts, were found at all of these sites. Bachmayerella tenuis was described by Rögl and Franz (1979) and Szczechura (1986) as a problematic middle Miocene microfossil of the Paratethys. However, based on the microcrystalline wall texture with elongated calcite microcrystals that are oriented perpendicular to the surface of the cyst, it is currently considered a calcdinocyst (Kohring, 1993; this paper).

In the Eastern Mediterranean, Pliocene-Pleistocene sedimentary sequences were previously recovered during Deep Sea Drilling Project (DSDP) Legs 13 and 42A (Ryan, Hsü, et al., 1973; Hsü, Montadert, et al., 1978) and ODP Leg 107 (Kastens, Mascle, Auroux, et al., 1987). However, B. tenuis and Incertae sedis, forma A, were never described for this area.

This paper deals also with the distribution and stable isotope composition of Incertae sedis, forma A, recovered in Pliocene and Pleistocene sediments from Holes 965A, 966A, 967A, and 969A.

${ }^{1}$ Robertson, A.H.F., Emeis, K.-C., Richter, C., and Camerlenghi, A. (Eds.), 1998. Proc. ODP, Sci. Results, 160: College Station, TX (Ocean Drilling Program).

${ }^{2}$ ETH-Zentrum, Geologisches Institut, Sonneggstrasse 5, 8092 Zurich, Switzerland. silvia@erdw.ethz.ch

${ }^{3}$ Geomar Research Center for Marine Geosciences, Wischhofstrasse 1-3, Building 4, 24148 Kiel, Federal Republic of Germany.

\section{MATERIALS AND METHODS}

Foraminifer samples were also used for $B$. tenuis and Incertae sedis, forma A, studies. Core catchers and 1-5 samples of $10 \mathrm{~cm}^{3}$ per section of each core were analyzed. Forty-two samples were studied for Hole 965A, from 0.33 to 28.8 meters below seafloor (mbsf; Samples $160-965 \mathrm{~A}-1 \mathrm{H}-1,32-34 \mathrm{~cm}$, through $4 \mathrm{H}-\mathrm{CC})$. Fifty-four samples were studied for Hole 966A, from 1.24 rmcd (revised meter composite depth; see Sakamoto et al. [Chap. 4, this volume], for conversion tables) to $\sim 80 \mathrm{rmcd}$ (Samples 160-966A-1H-1, 110-112 cm, to $9 \mathrm{H}-1,47-48 \mathrm{~cm})$. One hundred and twenty-one samples were studied for Hole 967A, from 1.07 to $126.41 \mathrm{rmcd}$ (Samples 160-967A$1 \mathrm{H}-1,106-108 \mathrm{~cm}$, to $13 \mathrm{H}-3,113-115 \mathrm{~cm})$. Forty-six samples were studied for Hole 969A, from 0.65 to 128.85 rmcd (Samples 160969A-1H-1, 63-65 cm, through 11H-CC). List of samples, ranges of B. tenuis and Incertae sedis, forma A (rmcd or mbsf), plotted vs. planktonic foraminifer and calcareous nannofossil zones and ages are given in Tables 2 through 5. Composite depth is used, when available, to facilitate correlation with other studies presented in this volume.

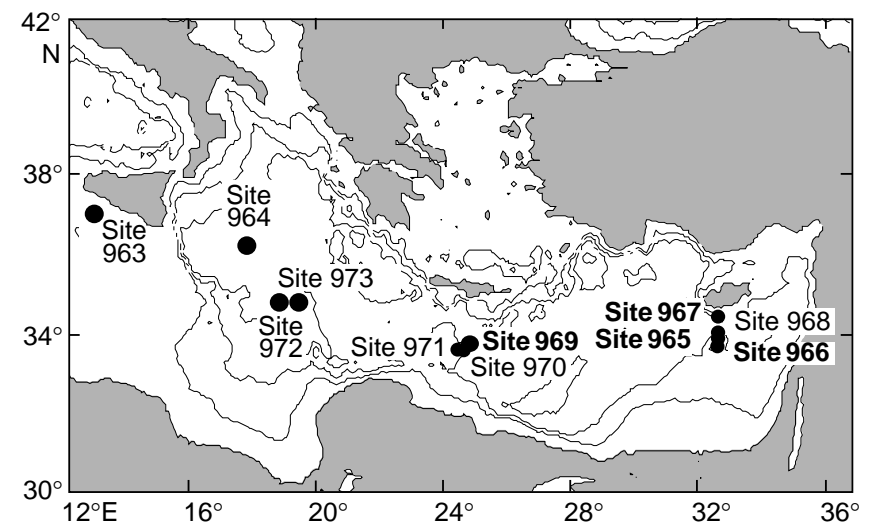

Figure 1. Location of Sites 963-973 in the Eastern Mediterranean. The investigated holes are marked in bold. 
Table 1. Geographic coordinates, water depth, and depth penetration of the holes drilled during Leg 160.

\begin{tabular}{ccccc}
\hline Hole & Latitude & Longitude & $\begin{array}{c}\text { Water depth } \\
(\mathrm{m})\end{array}$ & $\begin{array}{c}\text { Penetration } \\
(\mathrm{m})\end{array}$ \\
\hline $965 \mathrm{~A}$ & $33^{\circ} 55.080^{\prime} \mathrm{N}$ & $32^{\circ} 42.785^{\prime} \mathrm{E}$ & 1506.6 & 250.4 \\
$966 \mathrm{~A}$ & $33^{\circ} 47.799^{\prime} \mathrm{N}$ & $32^{\circ} 42.095^{\prime} \mathrm{E}$ & 926.6 & 106.8 \\
$967 \mathrm{~A}$ & $34^{\circ} 04.098^{\prime} \mathrm{N}$ & $32^{\circ} 43.523^{\prime} \mathrm{E}$ & 2553 & 141.3 \\
$969 \mathrm{~A}$ & $33^{\circ} 50.399^{\prime} \mathrm{N}$ & $24^{\circ} 53.065^{\prime} \mathrm{E}$ & 2200.3 & 108.3
\end{tabular}

Table 2. Samples and occurrences of Bachmayerella tenuis and Incertae sedis, forma A, plotted vs. planktonic foraminifer and calcareous nannofossil zones identified in Hole 965A.

\begin{tabular}{|c|c|c|c|c|c|c|c|}
\hline $\begin{array}{l}\text { 160-965A } \\
\text { Core, section, } \\
\text { interval }(\mathrm{cm})\end{array}$ & 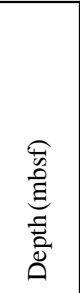 & 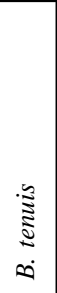 & 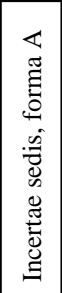 & 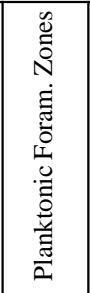 & 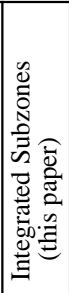 & 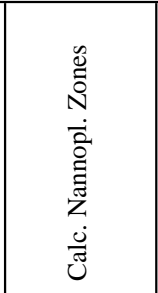 & $\stackrel{8}{<}$ \\
\hline $1 \mathrm{H}-1,32-34$ & 0.33 & - & - & \multirow{25}{*}{ 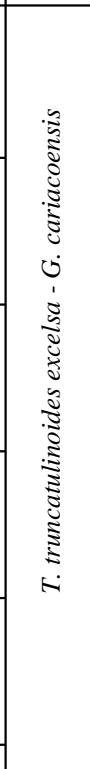 } & \multirow{10}{*}{$\mathrm{C}$} & MNN21b & \multirow{13}{*}{$\Sigma$} \\
\hline $\begin{array}{l}1 \mathrm{H}-1,43-46 \\
1 \mathrm{H}-\mathrm{CC}\end{array}$ & $\begin{array}{l}0.45 \\
0.60\end{array}$ & - & - & & & MNN21a & \\
\hline $\begin{array}{l}1 \mathrm{H}-\mathrm{CC} \\
2 \mathrm{H}-1,20-22\end{array}$ & 1.01 & - & - & & & & \\
\hline $2 \mathrm{H}-2,31-33$ & 2.62 & - & - & & & MNN20 & \\
\hline $2 \mathrm{H}-2,67-71$ & 2.98 & - & - & & & MNNZO & \\
\hline $2 \mathrm{H}-2,105-107$ & 3.36 & - & - & & & \multirow{8}{*}{ MNN19f } & \\
\hline $2 \mathrm{H}-3,9-11$ & 3.90 & - & - & & & & \\
\hline $2 \mathrm{H}-3,21-23$ & 4.04 & - & - & & & & \\
\hline $2 \mathrm{H}-3,64-66$ & 4.45 & - & - & & & & \\
\hline $2 \mathrm{H}-3,119-121$ & 5.00 & - & ID & & & & \\
\hline $2 \mathrm{H}-4,9-11$ & 5.40 & - & VR & & \multirow{9}{*}{ B } & & \\
\hline $2 \mathrm{H}-4,22-24$ & 5.53 & - & - & & & & \\
\hline $2 \mathrm{H}-4,57-59$ & 5.85 & - & VR & & & & \\
\hline $2 \mathrm{H}-4,124-126$ & 6.65 & - & - & & & \multirow{10}{*}{ MNN19e } & \multirow{12}{*}{ 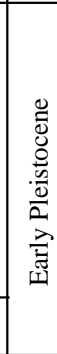 } \\
\hline $2 \mathrm{H}-5,27-29$ & 7.08 & - & VR & & & & \\
\hline $2 \mathrm{H}-5,60-62$ & 7.41 & - & $\mathrm{R}$ & & & & \\
\hline $2 \mathrm{H}-5,81-83$ & 7.61 & - & $\mathrm{R}$ & & & & \\
\hline $2 \mathrm{H}-5,139-141$ & 8.20 & - & VR & & & & \\
\hline $2 \mathrm{H}-6,21-23$ & 8.52 & - & $\mathrm{R}$ & & & & \\
\hline $2 \mathrm{H}-6,59-61$ & 8.90 & $\mathrm{R}$ & $\mathrm{R}$ & & \multirow{6}{*}{ A } & & \\
\hline $2 \mathrm{H}-6,104-106$ & 9.35 & - & VR & & & & \\
\hline $2 \mathrm{H}-6,131-133$ & 9.62 & - & $\mathrm{R}$ & & & & \\
\hline $2 \mathrm{H}-7,2-4$ & 9.83 & $\mathrm{R}$ & $\mathrm{R} / \mathrm{C}$ & & & & \\
\hline $2 \mathrm{H}-7,32-34$ & 10.12 & VR & $\mathrm{C}$ & & & MNN19d & \\
\hline $2 \mathrm{H}-\mathrm{CC}$ & 10.65 & $\mathrm{R}$ & $\mathrm{R} / \mathrm{C}$ & & & & \\
\hline $3 \mathrm{H}-1,69-71$ & 11.00 & $\mathrm{R}$ & $\mathrm{C}$ & \multirow{5}{*}{ MPl5b } & \multirow{6}{*}{\multicolumn{2}{|c|}{ MNN18 }} & \multirow{6}{*}{ 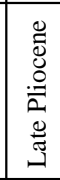 } \\
\hline $3 \mathrm{H}-2,7-9$ & 11.88 & VR & $\mathrm{C}$ & & & & \\
\hline $3 \mathrm{H}-2,67-69$ & 12.48 & $\mathrm{R}$ & A & & & & \\
\hline $3 \mathrm{H}-2,129-131$ & 13.10 & $\mathrm{R}$ & $\mathrm{R} / \mathrm{C}$ & & & & \\
\hline $3 \mathrm{H}-3,17-19$ & 13.48 & $\mathrm{R} / \mathrm{C}$ & $\mathrm{C} / \mathrm{A}$ & & & & \\
\hline $3 \mathrm{H}-4,17-19$ & 14.98 & $\mathrm{R} / \mathrm{C}$ & $\mathrm{R}$ & \multirow{7}{*}{ MPI5a } & & & \\
\hline $3 \mathrm{H}-4,32-34$ & 15.13 & VR & $\mathrm{R}$ & & & \multirow{5}{*}{ MNN17/16b } & \multirow{6}{*}{ 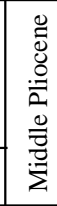 } \\
\hline $3 \mathrm{H}-4,135-137$ & 16.16 & & $\mathrm{C}$ & & & & \\
\hline $3 \mathrm{H}-5,29-31$ & 16.50 & VR & $\mathrm{C}$ & & & & \\
\hline $3 \mathrm{H}-5,35-37$ & 16.66 & - & $\mathrm{C}$ & & & & \\
\hline $3 \mathrm{H}-6,9-11$ & 17.90 & - & $\mathrm{R} / \mathrm{C}$ & & & & \\
\hline $\begin{array}{l}3 \mathrm{H}-6,123-125 \\
3 \mathrm{H}-\mathrm{CC}\end{array}$ & $\begin{array}{l}19.04 \\
20.00\end{array}$ & $\begin{array}{l}- \\
-\end{array}$ & \begin{tabular}{|l|} 
C/A \\
VR
\end{tabular} & & & MNN16a & \\
\hline $4 \mathrm{H}-1,95-97$ & 20.76 & - & VR & \multirow{3}{*}{ MPI4a } & & \begin{tabular}{|l|} 
MNN14/15 \\
\end{tabular} & \multirow{3}{*}{ 줗ํ. } \\
\hline $4 \mathrm{H}-6,29-31$ & 27.6 & - & - & & & & \\
\hline $4 \mathrm{H}-\mathrm{CC}$ & 28.8 & - & - & & & MNN13/12? & \\
\hline
\end{tabular}

Notes: Depth in meters below seafloor. See text for legend.

Sediments were soaked in distilled water and then washed under running water through a $40-\mu \mathrm{m}$ mesh sieve. Therefore, specimens smaller than $40 \mu \mathrm{m}$ in diameter were not investigated. Samples were then dried at room temperature for stable isotope analyses. The specimens of B. tenuis and Incertae sedis, forma A, were picked from the 40- to 160- $\mu \mathrm{m}$ size fractions. The abundance of these forms shown in the range charts is based on quantitative estimates as follows: $\mathrm{VA}=$
Table 3. Samples and occurrences of Bachmayerella tenuis and Incertae sedis, forma A, plotted vs. planktonic foraminifer and calcareous nannofossil zones identified in Hole 966A.

\begin{tabular}{|c|c|c|c|c|c|c|c|}
\hline $\begin{array}{l}160-966 \mathrm{~A} \\
\text { Core, section, } \\
\text { interval }(\mathrm{cm})\end{array}$ & 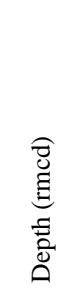 & 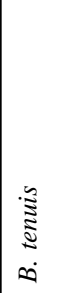 & 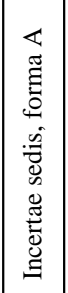 & 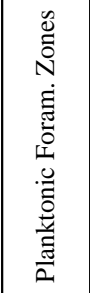 & 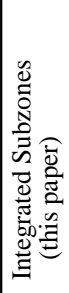 & 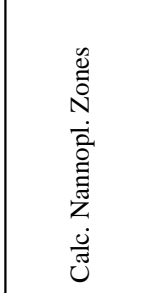 & $\underset{\infty}{\infty}$ \\
\hline $1 \mathrm{H}-1,110-112$ & 1.24 & - & - & \multirow{27}{*}{ 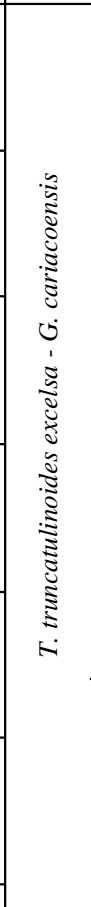 } & \multirow{13}{*}{$\mathrm{C}$} & MNN21a & \multirow{14}{*}{ 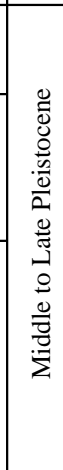 } \\
\hline $1 \mathrm{H}-2,110-112$ & 2.79 & - & - & & & MNN21b & \\
\hline $1 \mathrm{H}-3,52-54$ & 3.69 & - & - & & & \multirow{5}{*}{ MNN20 } & \\
\hline $\begin{array}{l}1 \mathrm{H}-4,35-37 \\
1 \mathrm{H}-\mathrm{CC}\end{array}$ & $\begin{array}{l}5.03 \\
7.60\end{array}$ & $\begin{array}{l}- \\
-\end{array}$ & - & & & & \\
\hline $2 \mathrm{H}-1,30-32$ & 7.98 & - & - & & & & \\
\hline $2 \mathrm{H}-1,126-128$ & 9.00 & - & - & & & & \\
\hline $2 \mathrm{H}-2,30-32$ & 9.59 & - & - & & & & \\
\hline $\mid \begin{array}{l}2 \mathrm{H}-2,126-128 \\
2 \mathrm{H}-3,30-32\end{array}$ & $\begin{array}{l}10.68 \\
11.25\end{array}$ & - & - & & & \multirow{7}{*}{ MNN19f } & \\
\hline $\mid 2 \mathrm{H}-3,126-128$ & 12.32 & - & - & & & & \\
\hline $2 \mathrm{H}-4,82-84$ & 13.53 & - & - & & & & \\
\hline $2 \mathrm{H}-4,125-127$ & 14.06 & - & - & & & & \\
\hline $2 \mathrm{H}-5,29-31$ & 14.74 & - & - & & & & \\
\hline $2 \mathrm{H}-5,125-127$ & 15.99 & - & - & & & & \\
\hline $2 \mathrm{H}-6,19-21$ & 16.51 & - & $\mathrm{R}$ & & \multirow{7}{*}{ B } & & \\
\hline $2 \mathrm{H}-\mathrm{CC}$ & 17.06 & - & & & & \multirow{7}{*}{ MNN19e } & \multirow{13}{*}{ 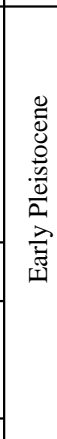 } \\
\hline $3 \mathrm{H}-1,56-58$ & 19.23 & - & - & & & & \\
\hline $3 \mathrm{H}-1,129-131$ & 20.06 & - & & & & & \\
\hline \begin{tabular}{|l|}
$3 \mathrm{H}-2,56-58$ \\
$3 \mathrm{H}-2,129-13$
\end{tabular} & $\frac{20.83}{21.80}$ & - & $\frac{\mathrm{cf}}{-}$ & & & & \\
\hline $3 \mathrm{H}-3,56-58$ & 22.63 & - & $\mathrm{R}$ & & & & \\
\hline $3 \mathrm{H}-3,129-131$ & 23.44 & & $\mathrm{R}$ & & & & \\
\hline $3 \mathrm{H}-4,14-16$ & 23.87 & VR & $\mathrm{R} / \mathrm{C}$ & & \multirow{7}{*}{ A } & & \\
\hline $3 \mathrm{H}-4,139-141$ & 25.48 & $\mathrm{R}$ & $\mathrm{R} / \mathrm{C}$ & & & \multirow[t]{2}{*}{ MNN19d } & \\
\hline $3 \mathrm{H}-5,14-16$ & 25.78 & $\mathrm{R}$ & $\mathrm{R} / \mathrm{C}$ & & & & \\
\hline $3 \mathrm{H}-5,129-131$ & 27.09 & $\mathrm{R} / \mathrm{C}$ & $\mathrm{R}$ & & & \multirow{3}{*}{ MNN19c-b } & \\
\hline $\begin{array}{l}3 \mathrm{H}-6,7-9 \\
3 \mathrm{H}-6,129-131\end{array}$ & $\begin{array}{l}27.48 \\
28.74\end{array}$ & $\begin{array}{l}\mathrm{R} / \mathrm{C} \\
\mathrm{R} / \mathrm{C}\end{array}$ & $\begin{array}{l}\mathrm{R} \\
\mathrm{R}\end{array}$ & & & & \\
\hline $3 \mathrm{H}-\mathrm{CC}$ & 28.78 & $\mathrm{R} / \mathrm{C}$ & $\mathrm{R} / \mathrm{C}$ & & & & \\
\hline $4 \mathrm{H}-1,29-31$ & 30.18 & $\mathrm{R}$ & $\mathrm{R} / \mathrm{C}$ & & & MNN19a & \\
\hline $4 \mathrm{H}-2,29-31$ & 31.78 & $\mathrm{R}$ & $\mathrm{C}$ & \begin{tabular}{|l|} 
MPI6 \\
\end{tabular} & & \multirow{3}{*}{ MNN18 } & \multirow{3}{*}{ 兽 } \\
\hline $4 \mathrm{H}-3,63-65$ & 33.79 & $\mathrm{R} / \mathrm{C}$ & $\mathrm{C}$ & MPl5b & & & \\
\hline $4 \mathrm{H}-4,80-82$ & 35.70 & $\begin{array}{l}\mathrm{R} \\
\mathrm{R}\end{array}$ & $\begin{array}{c}\mathrm{C} \\
\mathrm{C} / \mathrm{A}\end{array}$ & & & & \\
\hline$\frac{4 \mathrm{H}-5,80-82}{4 \mathrm{H}-6,37-39}$ & $\begin{array}{l}37.56 \\
38.69\end{array}$ & $\frac{\mathrm{R}}{\mathrm{R}}$ & \begin{tabular}{|l|} 
C/A \\
VR \\
\end{tabular} & \multirow{4}{*}{ MPl5a } & & \multirow[b]{2}{*}{ MNN17-16b } & \multirow{7}{*}{ 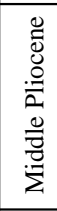 } \\
\hline $\begin{array}{l}4 \mathrm{H}-6,37-39 \\
4 \mathrm{H}-\mathrm{CC}\end{array}$ & $\begin{array}{l}38.69 \\
39.78\end{array}$ & $\begin{array}{l}\mathrm{K} \\
-\end{array}$ & C & & & & \\
\hline $5 \mathrm{H}-1,98-100$ & 42.38 & $\mathrm{R}$ & A & & & \multirow{7}{*}{ MNN16a } & \\
\hline $5 \mathrm{H}-3,130-132$ & 45.81 & - & A & & & & \\
\hline $5 \mathrm{H}-5,61-63$ & 48.22 & 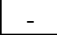 & A & & & & \\
\hline $5 \mathrm{H}-6,45-49$ & 49.49 & 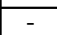 & $\mathrm{C}$ & MPI4b & & & \\
\hline $5 \mathrm{H}-\mathrm{CC}$ & 50.28 & & & & & & \\
\hline $6 \mathrm{H}-1,93-95$ & 53.69 & VR & $\mathrm{R}$ & \multirow{3}{*}{ MP14a } & & & \multirow{9}{*}{ 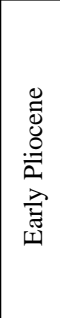 } \\
\hline $6 \mathrm{H}-3,46-48$ & 56.68 & $\mathrm{R}$ & $\mathrm{R} / \mathrm{C}$ & & & & \\
\hline $6 \mathrm{H}-4,114-116$ & 59.15 & VR & VR & & & \multirow{2}{*}{ MNN14-15 } & \\
\hline $6 \mathrm{H}-6,25-27$ & 61.60 & - & A & \multirow{5}{*}{ MPI3 } & & & \\
\hline $6 \mathrm{H}-\mathrm{CC}$ & 64.06 & & $\mathrm{R}$ & & & \multirow[b]{2}{*}{ MNN13 ? } & \\
\hline $7 \mathrm{H}-1,94-96$ & $\begin{array}{l}66.31 \\
66.08\end{array}$ & - & $\mid \begin{array}{l}\mathrm{R} / \mathrm{C} \\
\mathrm{R} / \mathrm{C}\end{array}$ & & & & \\
\hline $\begin{array}{l}7 \mathrm{H}-3,71-73 \\
7 \mathrm{H}-5,47-48\end{array}$ & $\begin{array}{l}66.98 \\
67.02\end{array}$ & - & $\begin{array}{c}\mathrm{R} / \mathrm{C} \\
\mathrm{R}\end{array}$ & & & & \\
\hline $7 \mathrm{H}-5,81-83$ & 67.03 & & & & & & \\
\hline $\begin{array}{l}7 \mathrm{H}-\mathrm{CC} \\
8 \mathrm{H}-\mathrm{CC}\end{array}$ & & - & $\begin{array}{c}- \\
\mathrm{VR}\end{array}$ & MPI2 & & & \\
\hline
\end{tabular}

Note: Depth in revised meters composite depth.

very abundant, $>20$ specimens/field of view; $\mathrm{A}=$ abundant, $>10$ specimens/field of view; $\mathrm{C}=$ common, $1-10$ specimens/field of view; $\mathrm{R}$ = rare, 1 specimen/2-10 fields of view; and VR = very rare, 1 specimen/>field of view. The preservation of specimens is moderate to good throughout the sequences.

About 100 to 200 specimens of Incertae sedis, forma A, were picked in selected samples for isotope analyses. About 20 specimens 
Table 4. Samples and occurrences of Bachmayerella tenuis and Incertae sedis, forma A, plotted vs. planktonic foraminifer and calcareous nannofossil zones identified in Hole 967A.

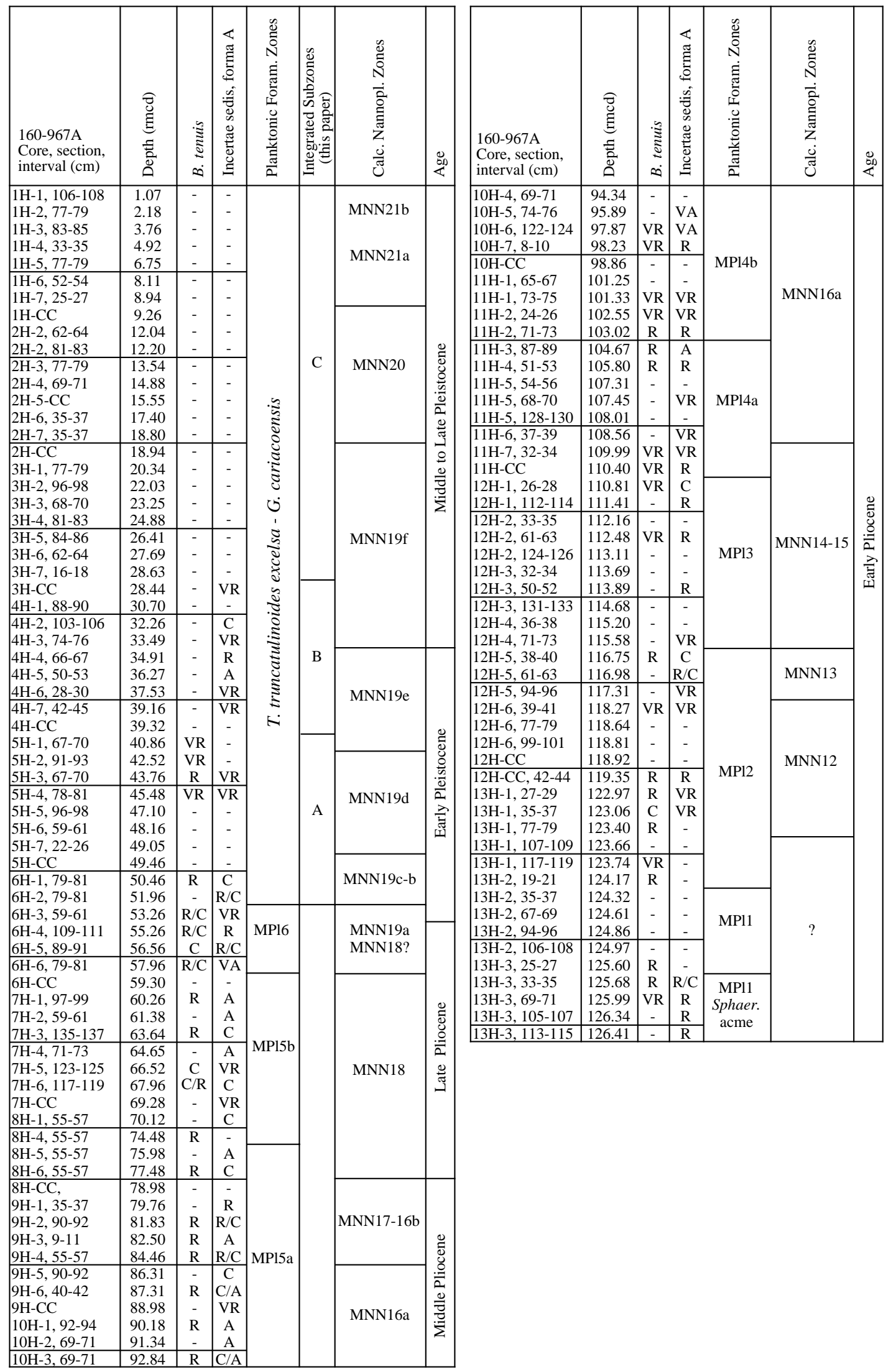

Note: Depth in revised meters composite depth. 
Table 5. Samples and occurrences of Bachmayerella tenuis and Incertae sedis, forma A, plotted vs. planktonic foraminifer and calcareous nannofossil zones identified in Hole 969A.

\begin{tabular}{|c|c|c|c|c|c|c|c|}
\hline $\begin{array}{l}\text { 160-969A } \\
\text { Core, section, } \\
\text { interval }(\mathrm{cm})\end{array}$ & 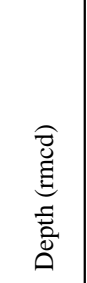 & 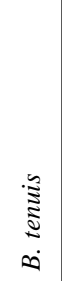 & 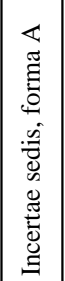 & 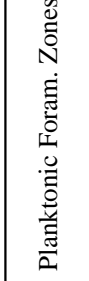 & 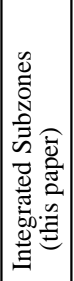 & 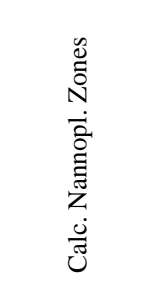 & $\stackrel{8}{\pi}$ \\
\hline $1 \mathrm{H}-1,63-65$ & 0.65 & - & - & \multirow{22}{*}{ 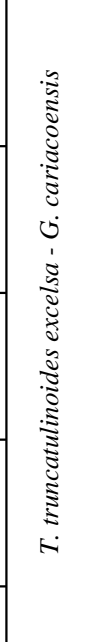 } & \multirow{11}{*}{$\mathrm{C}$} & & \multirow{12}{*}{ 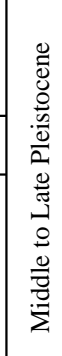 } \\
\hline $1 \mathrm{H}-3,65-67$ & 3.22 & - & - & & & MNN21b & \\
\hline $1 \mathrm{H}-5,67-69$ & 6.06 & - & - & & & MNN21a & \\
\hline $1 \mathrm{H}-\mathrm{CC}$ & 6.76 & - & - & & & & \\
\hline $2 \mathrm{H}-1,122-124$ & 8.09 & - & - & & & & \\
\hline $2 \mathrm{H}-3,35-36$ & 9.89 & - & - & & & MNN20 & \\
\hline $2 \mathrm{H}-4,40-41$ & 11.74 & - & - & & & \multirow{7}{*}{ MNN19f } & \\
\hline $2 \mathrm{H}-5,110-112$ & 13.97 & - & - & & & & \\
\hline $2 \mathrm{H}-6,70-71$ & 16.89 & - & - & & & & \\
\hline $2 \mathrm{H}-7,10-12$ & 17.69 & - & - & & & & \\
\hline $2 \mathrm{H}-\mathrm{CC}$ & 18.20 & - & - & & & & \\
\hline $3 \mathrm{H}-1,21-22$ & 19.00 & - & $\mathrm{R}$ & & \multirow{4}{*}{ B } & & \\
\hline $3 \mathrm{H}-1,60-61$ & 19.30 & - & VR & & & & \multirow{9}{*}{ 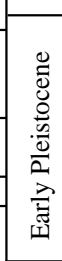 } \\
\hline $3 \mathrm{H}-2,15-17$ & 20.26 & - & $\mathrm{R}$ & & & \multirow{3}{*}{ MNN19e } & \\
\hline $3 \mathrm{H}-3,115-117$ & 25.76 & - & - & & & & \\
\hline $3 \mathrm{H}-5,31-33$ & 28.63 & $\mathrm{R} / \mathrm{C}$ & - & & \multirow{7}{*}{ A } & & \\
\hline $3 \mathrm{H}-6,2-4$ & 29.50 & $\mathrm{R}$ & $\mathrm{C}$ & & & MNN19d & \\
\hline $3 \mathrm{H}-\mathrm{CC}$ & 32.32 & $\mathrm{R} / \mathrm{C}$ & $\mathrm{R}$ & & & ININIVI9d & \\
\hline $4 \mathrm{H}-1,131-133$ & 35.41 & $\mathrm{R}$ & $\mathrm{C}$ & & & MNN19c-19b & \\
\hline $4 \mathrm{H}-3,9-11$ & 37.61 & $\mathrm{R}$ & $\mathrm{A}$ & & & \multirow{4}{*}{ MNN19a } & \\
\hline $4 \mathrm{H}-4,9-11$ & 39.53 & $\mathrm{R} / \mathrm{C}$ & $\mathrm{C}$ & & & & \\
\hline $4 \mathrm{H}-5,3-5$ & 42.03 & $\mathrm{R} / \mathrm{C}$ & $\mathrm{C} / \mathrm{A}$ & & & & \multirow{3}{*}{ 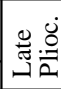 } \\
\hline $4 \mathrm{H}-6,5-7$ & 44.60 & $\mathrm{R} / \mathrm{C}$ & $\mathrm{C}$ & MPl6 & & & \\
\hline $4 \mathrm{H}-\mathrm{CC}$ & 47.78 & $\mathrm{R}$ & $\mathrm{R} / \mathrm{C}$ & \multirow{4}{*}{ MPl5b } & & \multirow{2}{*}{$\begin{array}{l}\text { MNN18 to } \\
\text { MNN16b }\end{array}$} & \\
\hline $5 \mathrm{H}-\mathrm{CC}$ & 61.35 & $\mathrm{R}$ & $\mathrm{R}$ & & & & \multirow{5}{*}{ 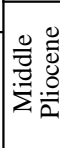 } \\
\hline $6 \mathrm{H}-\mathrm{CC}$ & 74.02 & - & - & & & \multirow{9}{*}{ MNN16a } & \\
\hline $7 \mathrm{H}-1,121-123$ & 77.03 & $\mathrm{R}$ & $\mathrm{C} / \mathrm{A}$ & & & & \\
\hline $7 \mathrm{H}-2,116-120$ & 79.34 & - & VR & \begin{tabular}{|l|} 
MPl5a \\
\end{tabular} & & & \\
\hline $7 \mathrm{H}-3,120-122$ & 81.05 & $\mathrm{R}$ & $\mathrm{C}$ & MPl4b & & & \\
\hline $7 \mathrm{H}-4,117-119$ & 82.76 & - & $\mathrm{C} / \mathrm{A}$ & \multirow{5}{*}{ MPl4a } & & & \multirow{17}{*}{ 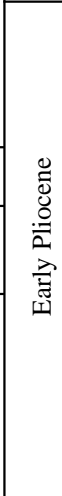 } \\
\hline $7 \mathrm{H}-5,122-124$ & 84.25 & - & $\mathrm{C} / \mathrm{A}$ & & & & \\
\hline $7 \mathrm{H}-6,83-85$ & 85.15 & - & - & & & & \\
\hline $7 \mathrm{H}-\mathrm{CC}$ & 85.69 & - & - & & & & \\
\hline $8 \mathrm{H}-5,43-45$ & 93.35 & - & - & & & & \\
\hline $8 \mathrm{H}-\mathrm{CC}$ & 97.03 & $\mathrm{R}$ & $\mathrm{R} / \mathrm{C}$ & \multirow{5}{*}{ MP13 } & & \multirow[t]{2}{*}{ MNN14-15 } & \\
\hline $9 \mathrm{H}-1,110-112$ & 99.70 & VR & $\mathrm{R} / \mathrm{C}$ & & & & \\
\hline $9 \mathrm{H}-3,48-50$ & 102.58 & $\mathrm{R}$ & $\mathrm{R} / \mathrm{C}$ & & & \multirow{3}{*}{ MNN13 } & \\
\hline $9 \mathrm{H}-5,38-40$ & 105.68 & $\mathrm{R}$ & - & & & & \\
\hline $9 \mathrm{H}-\mathrm{CC}$ & 109.25 & - & - & & & & \\
\hline $10 \mathrm{H}-3,100-102$ & 115.64 & VR & - & \multirow{4}{*}{ MP12 } & & \multirow{7}{*}{ MNN12 } & \\
\hline $10 \mathrm{H}-4,134-136$ & 117.51 & VR & - & & & & \\
\hline $10 \mathrm{H}-6,91-93$ & 120.06 & - & - & & & & \\
\hline $10 \mathrm{H}-\mathrm{CC}$ & 121.23 & - & - & & & & \\
\hline $11 \mathrm{H}-2,14-16$ & 123.08 & $\mathrm{VR}$ & - & \multirow{3}{*}{ MP11 } & & & \\
\hline $11 \mathrm{H}-4,27-31$ & 126.20 & VR & - & & & & \\
\hline $11 \mathrm{H}-\mathrm{CC}$ & 129.95 & - & - & & & & \\
\hline
\end{tabular}

Note: Depth in revised meters composite depth.

of the planktonic foraminifer Globigerinoides obliquus and about 10 specimens of the benthic foraminifer Oridorsalis stellatus were also picked from the same samples for comparison. Oxygen and carbon isotopes were measured using a PRISM Mass Spectrometer at ETHZürich. The isotope data, corrected following the procedure of Craig (1957), modified for a triple collector and relative to the international standard Peedee Belemnite (PDB), are given in Table 6.

\section{TAXONOMY}

Bachmayerella tenuis Rögl and Franz, 1979

Plate 1, Figs. 4-9

Bachmayerella tenuis Rögl and Franz, 1979, p. 90, pl. 1, figs. 9-14, pl. 4, figs. 35-39, pl. 5, figs. 39-40. Szczechura, 1986, p. 225, pl. 22, figs. 3-4, pl. 27 , figs. $1,2,4-8$.

Description: The calcareous cyst is strictly spherical, $110-130 \mu \mathrm{m}$ in diameter, with an apical circular archaeophyle of 25-35 $\mu \mathrm{m}$ in diameter. Cyst surface is covered all over by a regular pattern of 5- to 6-edged reticulations. There are 10-11 reticulations per test diameter. Some distinct pores are present on the intersection of the ridges, forming the reticulations. Pores are irregularly distributed over the test. The single-layered wall of $10 \mu \mathrm{m}$ thickness consists of elongated calcite microcrystals, oriented perpendicular to the surface of the cyst.

Remarks: In Leg 160 material, B. tenuis sensu strictu occurs together with specimens that display a bigger test (diameter 140-170 $\mu \mathrm{m}$ ), a diameter of apicale circular archaeophyle of $\sim 35 \mu \mathrm{m}$, coarser and more irregular reticulations of the wall texture ( $\sim 9$ per test diameter), and bigger pores and pores on the ridges and between the reticulations. In this paper, these specimens are informally called Bachmayerella cf. tenuis (Plate 1, Figs. 1-3). However, further studies on the wall texture are in progress to clarify their taxonomic position.

Occurrence: ODP Leg 160 Sites 963-969, 972, and 973: Pliocene-early Pleistocene Zone MP11 to Globigerina cariacoensis-Truncorotalia truncatulinoides excelsa interval (planktonic foraminifers); Zone MNN12 to the base of Zone MNN19e (calcareous nannofossils).

Austria: Middle Miocene, upper part of the middle Badenian of the Vienna Basin, Walbersdorf, Buliminen-Bolivinen Zone (benthic foraminifers); Zone NN6 (calcareous nannofossils); Bolboforma badenensis Zone (Bolboforma).

Poland: Middle Miocene, middle Badenian of the Carpathian Foredeep, Korythnica region.

Bulgaria: Middle Miocene, lower Badenian of the Dacian Basin, Opanetz, northwest of Pleven, Zones NN5/6 (calcareous nannofossils); upper Bolboforma reticulata Zone (Bolboforma).

Incertae sedis, forma $\mathrm{A}$, new form Plate 2, Figs. 1-11

Description: The calcareous cyst is round to elongate. The length ranges from 100 to $150 \mu \mathrm{m}$, and the diameter of the round portion is from 60 to 130 $\mu \mathrm{m}$. Wall texture is smooth, an elongated neck is almost always present (length 35-45 $\mu \mathrm{m}$ ), and the archaeophyle, if present, is concealed, terminal, and probably circular (further investigations are needed to confirm the presence of this structure). Some specimens may show remains of paracingulum (Pl. 2, Fig. 3). Further studies on the wall texture are currently underway to clarify its taxonomic position. However, the wall texture resembles that of calcdinocysts (Pl. 2, Figs. 10-11).

Remarks: In the studied material, this form shows a wide range of size and shape. Most of the studied specimens have calcareous infilling inside the test (Pl. 2, Fig. 10). However, no information on the origin of this calcareous infilling are currently available.

Occurrence: Eastern Mediterranean, ODP Leg 160 Sites 963-969, 972, and 973: Pliocene-early Pleistocene Zone MPL1 to $G$. cariacoensis- T. truncatulinoides excelsa interval (planktonic foraminifers); Zone MNN12 to the base of Zone MNN19f (calcareous nannofossils).

\section{BIOSTRATIGRAPHY}

Preliminary biostratigraphic data on Holes 965A, 966A, 967A, and 969A are reported in Emeis, Robertson, Richter, et al. (1996) and summarized below. Age determination for the Pliocene and Pleistocene sequences identified in this study are based on the planktonic 
foraminifer zonal schemes proposed by Cita (1975), as amended by Sprovieri $(1992,1993)$. Calcareous nannofossils zones are those proposed by Rio et al. (1990). However, the top of Zone MNN16 is identified in base of the last common occurrence (LCO) of Discoaster tamalis following Sprovieri (1993). Figure 2 reports the planktonic foraminifer and calcareous nannofossil zones and events and the ranges of $B$. tenuis and Incertae sedis, forma A, plotted vs. the geomagnetic time scale.

\section{Hole 965A}

Hole 965A is located on the upper slope of the Eratosthenes Seamount. Forty-two cores were retrieved. The advanced piston corer (APC) was used down to $29.3 \mathrm{mbsf}$, and the extended core barrel (XCB) was used down to $221.1 \mathrm{mbsf}$ (with a total core recovery of $17.0 \%$ ). The upper part of the condensed sedimentary sequence comprises $\sim 29 \mathrm{~m}$ of Pliocene-Quaternary nannofossil muds and oozes with rare sapropels.

\section{Planktonic Foraminifers}

Faunal assemblages are generally very well preserved and abundant throughout. The zonal boundary between the T. truncatulinoides excelsa and G. cariacoensis Zones was not recognized because of the scarcity of $T$. truncatulinoides excelsa. The interval spanning the two zones was identified from Samples 160-965A-1H, 32-34 cm, through $2 \mathrm{H}-\mathrm{CC}$ (from the seafloor to $10.65 \mathrm{mbsf}$ ). This extended biozone accounts for about one third of the entire sedimentary sequence (10.65 meters). Zones MP16 and MPl4a were not identified, suggesting the presence of a possible hiatus between the lower Pleistocene and the upper Pliocene and between the lower and mid-Pliocene sed- iments, respectively. Zone MPl5b was identified from Samples 160965A-3H-1, 69-71 cm, to $3 \mathrm{H}-3,17-19 \mathrm{~cm}$ (from 11 to $13.48 \mathrm{mbsf}$ ). Samples 160-965A-3H-4, 17-19 cm, through 3H-CC yield planktonic foraminifer assemblages attributed to Zone MPl5a (from 14.98 to 20 mbsf), whereas Zone MPl4a is identified from Samples 160965A-4H-1, 95-97 cm, through 4H-CC (from 20.76 to $28.8 \mathrm{mbsf}$ ).

\section{Calcareous Nannofossils}

Preservation of floral assemblages is very good for the Pleistocene samples and diminishes to fair in the Pliocene samples. Samples 160-965A-1H-1, 4 cm, through 1H-CC contain calcareous nannofossil assemblages attributed to Zone MNN21. Zone MNN20 is identified from Samples 160-965A-2H-1, $8 \mathrm{~cm}$, to $2 \mathrm{H}-2,133 \mathrm{~cm}$. Samples 160-965A-2H-3, $9 \mathrm{~cm}$, to $2 \mathrm{H}-4,104 \mathrm{~cm}$, contain nannofossils from Zone MNN19f, and Samples 160-965A-2H-4, $126 \mathrm{~cm}$, to 2H-7, $4 \mathrm{~cm}$, contain nannofossils from Zone MNN19e. Zone MNN19d is identified from Samples 160-965A-2H-7, $30 \mathrm{~cm}$, through 2H-CC. The assemblages from Sample 160-965A-3H-1, 20 $\mathrm{cm}$, to Sample 3H-4, $20 \mathrm{~cm}$, contain Discoaster brouweri and other species associated with Zone MNN18. In accordance to planktonic foraminifer data, a possible hiatus spans the interval between the early Pleistocene and the late Pliocene. The missing interval includes the calcareous nannofossil Zones MNN19c through MNN19a. Based on the common presence of D. pentaradiatus and D. surculus, Samples $160-965 \mathrm{~A}-3 \mathrm{H}-4,32 \mathrm{~cm}$, to $3 \mathrm{H}-6,20 \mathrm{~cm}$, are attributed to Zones MNN17 through MNN16b. The LCO of D. tamalis marks the top of Zone MNN16a, which is identified from Samples 160-965A-3H-6, $80 \mathrm{~cm}$, through $3 \mathrm{H}-\mathrm{CC}$. Samples 160-965A-4H-1, $95 \mathrm{~cm}$, to 4H-3, 54 $\mathrm{cm}$, contain nannofossils belonging to Zones MNN14 through MNN15. The interval from Samples 160-965A-4H-3, $125 \mathrm{~cm}$,

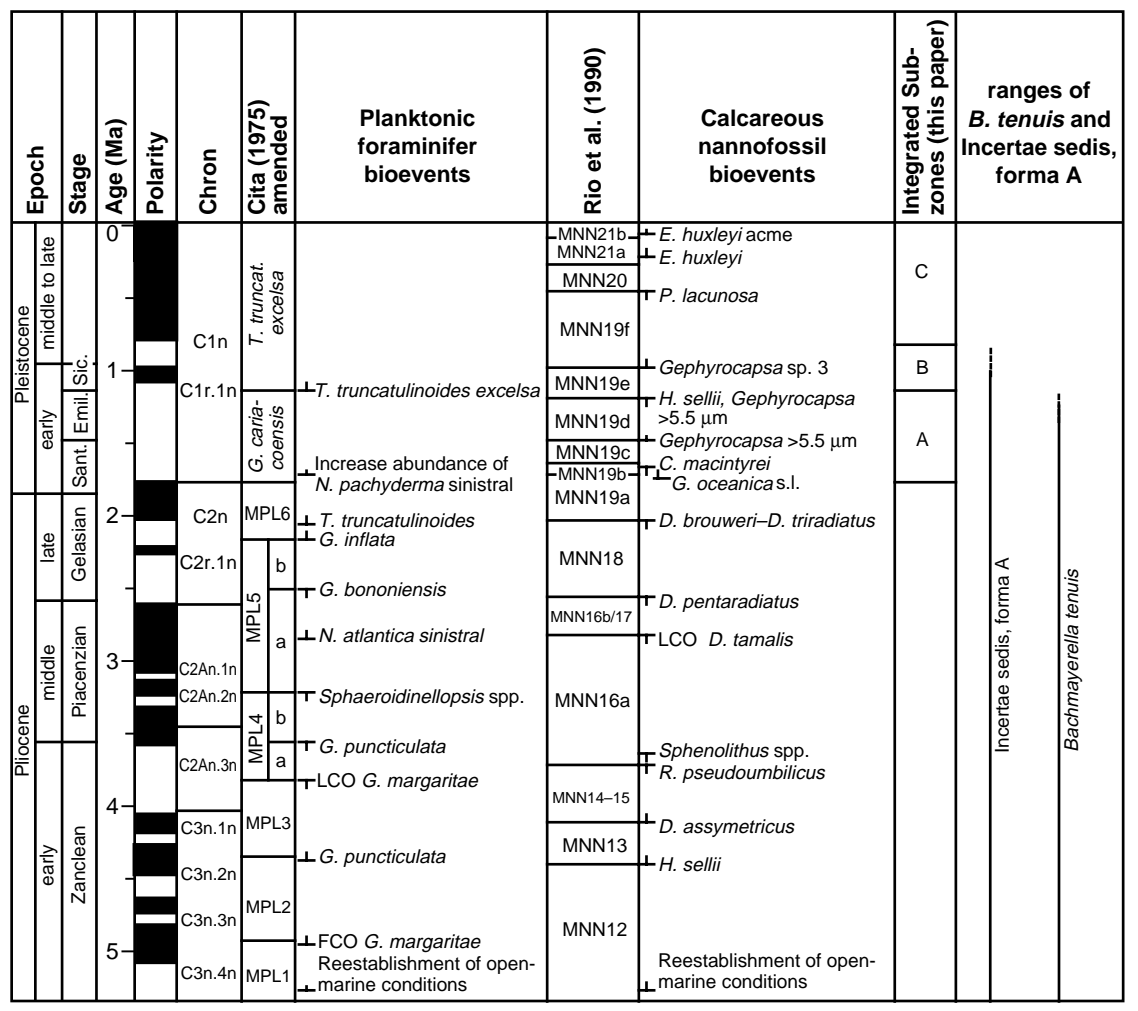

Figure 2. Correlation of Pliocene and Pleistocene nal nofossil, foraminifer, Bachmayerella tenuis, and Incertae sedis, forma $\mathrm{A}$, zones, events, and ranges in the Eastern Mediterranean with the geomagnetic polarity time scale of Shackleton et al. (1990) and Cande and Kent (1995). 
through $4 \mathrm{H}-\mathrm{CC}$ could not be confidently placed into a biozone because of poor preservation and a paucity of calcareous nannofossils.

\section{Bachmayerella tenuis and Incertae sedis, forma A}

Incertae sedis, forma A, occurs throughout the sequence. It is generally well preserved and very rare to abundant. It last occurs in Sample 160-965A-2H-4, 9-11 cm, within the T. truncatulinoides-G. cariacoensis Zones interval and in the lower part of Zone MNN19f.

Bachmayerella tenuis is rarer but also well preserved. It last occurs in Sample 160-965A-2H-6, 59-61 cm, within the T. truncatulinoides-G. cariacoensis Zones interval and in the lower part of Zone MNN19e (Table 2).

\section{Hole 966A}

Hole 966A is located on the northern edge of the plateau area of the Eratosthenes Seamount. Thirteen cores were recovered, with a core recovery of $68.5 \%$. The APC was used down to $68.3 \mathrm{mbsf}$ ( $72.5 \mathrm{rmcd})$. The XCB was used down to $106.8 \mathrm{mbsf}$. The upper part of the sedimentary sequence comprises $\sim 67 \mathrm{~m}$ of PlioceneQuaternary nannofossil muds and oozes with numerous sapropels.

\section{Planktonic Foraminifers}

Faunal assemblages are generally well preserved and abundant. However, abundance and preservation decrease in the lower part of the section. The $T$. truncatulinoides excelsa-G. cariacoensis Zones interval spans the entire Pleistocene from Samples 160-966A-1H-1, $110-112 \mathrm{~cm}$, to $4 \mathrm{H}-1,29-31 \mathrm{~cm}$ (from the seafloor to $30.18 \mathrm{rmcd}$ ). This extended zone accounts for about half of the entire sedimentary sequence recovered in this hole. Pliocene Zone MP16 was recognized only in Sample 160-966A-4H-2, 29-31 cm (31.78 rmcd). Zone MPl5b is identified from Samples 160-966A-4H-3, 63-65 cm, to 4H4, 80-82 cm (from 33.79 to 35.7 rmcd). Samples 160-966A-4H-5, $80-82 \mathrm{~cm}$, to $5 \mathrm{H}-3,130-132 \mathrm{~cm}$, contain Globorotalia bononiensis and are attributed to Zone MPI5a (from 37.56 to $45.81 \mathrm{rmcd}$ ). Zone MPl4b is identified from Samples 160-966A-5H-5, 61-63 cm, through 5H-CC (from 48.22 to $50.28 \mathrm{rmcd}$ ). Samples 160-966A-6H$1,93-95 \mathrm{~cm}$, to $6 \mathrm{H}-4,144-116 \mathrm{~cm}$, contain planktonic foraminifer assemblages attributed to Zone MP14a, whereas Zone MP13 is identified from Samples 160-966A-6H-6, 25-27 cm, to 7H-5, 81-83 cm (from 53.69 to $59.15 \mathrm{rmcd}$ and 61.6 to $67.03 \mathrm{rmcd}$, respectively). Samples $160-966 \mathrm{~A}-7 \mathrm{H}-\mathrm{CC}$ and $8 \mathrm{H}-\mathrm{CC}$ are attributed to Zone MPI2 based on the absence of Globorotalia puncticulata.

\section{Calcareous Nannofossils}

Calcareous nannofossil assemblages are generally diverse and well preserved throughout the section; their abundance and preservation, however, decrease toward the lower part of the sequence. The base of Zone MNN21 occurs in Sample 160-966A-1H-3, $140 \mathrm{~cm}$. Samples $160-966 \mathrm{~A}-1 \mathrm{H}-4,30 \mathrm{~cm}$, to $2 \mathrm{H}-2,30 \mathrm{~cm}$, are placed into Zone MNN20. Samples 160-966A-2H-2, $70 \mathrm{~cm}$, to $2 \mathrm{H}-6,55 \mathrm{~cm}$, contain nannofossils from Zone MNN19f. Zone MNN19e is identified from Samples 160-966A-2H-CC to $3 \mathrm{H}-4,80 \mathrm{~cm}$. Samples 160$966 \mathrm{~A}-3 \mathrm{H}-4,85 \mathrm{~cm}$, to $3 \mathrm{H}-5,80 \mathrm{~cm}$, contain nannofossils attributed to Zone MNN19d. The interval spanning Zones MNN19c-MNN19b is identified from Samples 160-966A-3H-5, $85 \mathrm{~cm}$, through 3H-CC. Samples $160-966 \mathrm{~A}-4 \mathrm{H}-1,15 \mathrm{~cm}$, to $4 \mathrm{H}-1,80 \mathrm{~cm}$, contain nannofossils from Zone MNN19a. Samples 160-966A-4H-1, $130 \mathrm{~cm}$, and 4H$5,130 \mathrm{~cm}$, contain nannofossils from Zone MNN18. Zone MNN1716 is identified from Samples 160-966A-4H-6, $10 \mathrm{~cm}$, through $4 \mathrm{H}-$ CC. Samples 160-966A-5H-1, $21 \mathrm{~cm}$, to $6 \mathrm{H}-3,149 \mathrm{~cm}$ contain nannofossils belonging to Zones MNN16a. The interval spanning Zones MNN14-15 is recognized from Samples 160-966A-6H-4, $42 \mathrm{~cm}$, to
6H-6, $68 \mathrm{~cm}$. Samples 160-966A-6H-6, $146 \mathrm{~cm}$, to 7H-4, $115 \mathrm{~cm}$, contain nannofossils belonging to the Zone MNN13. No nannofossils were identified in the sediments below.

\section{Bachmayerella tenuis and Incertae sedis, forma A}

Incertae sedis, forma $\mathrm{A}$, is rather continuously distributed throughout the sequence. It is generally well preserved and varies from level to level from very rare to abundant. Its last occurrence (LO) is observed in Sample 160-966A-2H-6, 19-21 cm, in the lower part of Zone MNN19f.

Bachmayerella tenuis is rarer and absent in the lower part of the sequence. It is generally well preserved even if some slightly corroded specimens occur throughout. It last occurs in Sample 160-966A$3 \mathrm{H}-4,14-16 \mathrm{~cm}$, in the lowermost part of Zone MNN19e (Table 3).

\section{Hole 967A}

Hole 967A is located on the lower northern slope of the Eratosthenes Seamount. Sixteen cores were recovered, with a core recovery of $95.8 \%$. The APC was used down to $123.3 \mathrm{mbsf}$ (between 127.83 and $137.57 \mathrm{rmcd}$ ). The XCB was used down to $141.3 \mathrm{mbsf}$. The upper part of the sedimentary sequence comprises $\sim 100 \mathrm{~m}$ of Pliocene-Quaternary nannofossil oozes, nannofossil clays, with numerous sapropels.

\section{Planktonic Foraminifers}

Planktonic foraminifers range in abundance from absent in the lower part of the section to dominant. They consist of diversified and poorly to well-preserved Pleistocene and Pliocene faunas. The zonal boundary between the T. truncatulinoides excelsa and G. cariacoensis Zones was not recognized. The base of the interval spanning the two biozones is identified in Sample 160-967A-6H-2, 79-81 cm (51.96 rmcd). This extended interval accounts for about one third of the entire sedimentary sequence. Zone MP16 is tentatively placed from Samples 160-6H-3, 59-61 cm, to $6 \mathrm{H}-6,79-81 \mathrm{~cm}$ (from 53.26 to $57.96 \mathrm{rmcd}$ ). However, its identification is based on the assemblages only, rather than the presence of markers. Therefore, it may be missing, as corroborated by the presence of debris flows within this interval (Emeis, Robertson, Richter, et al., 1996). Zone MPl5b is tentatively identified from Samples 160-967A-6H-CC to 160-967A-8H4, 55-57 cm (from 59.3 to 74.48 rmcd). Samples 160-967A-8H-5, $55-57 \mathrm{~cm}$, to $10 \mathrm{H}-3,69-61 \mathrm{~cm}$, are attributed to Zone MPl5a (from 75.98 to $92.84 \mathrm{rmcd})$. Zone MPl4b is identified from Samples 160967A-10H-4, 69-71 cm, to $11 \mathrm{H}-2,71-73 \mathrm{~cm}$ (from 94.34 to 103.02 rmcd). Zone MP14a is identified from Samples 160-967A-11H-3, $87-89 \mathrm{~cm}$, through $11 \mathrm{H}-\mathrm{CC}$ (from 104.67 to $110.4 \mathrm{rmcd}$ ) and Zone MPl3 from Samples 160-967A-12H-1, 26-28 cm, to 12H-4, 71-73 $\mathrm{cm}$ (from 110.81 to $115.58 \mathrm{rmcd}$ ). Samples 160-967A-12H-5, 38-40 $\mathrm{cm}$, to $13 \mathrm{H}-2,19-21 \mathrm{~cm}$ (from 116.75 to $124.17 \mathrm{rmcd}$ ), are attributed to Zone MP12 based on the absence of Globorotalia puncticulata. Samples 160-967A-13H-2, 35-37 cm, to $13 \mathrm{H}-3,113-115 \mathrm{~cm}$, contain Zone MPl1 (from 124.32 to $126.41 \mathrm{rmcd}$ ).

\section{Calcareous Nannofossils}

Calcareous nannofossils are abundant or common throughout the sequence. However, preservation varies from very good in the Pleistocene and upper Pliocene sediments to poor in some oozes and chalks associated with the lower Pliocene. The base of the youngest biozone (MNN21) was detected in Sample 160-967A-1H-7, $53 \mathrm{~cm}$. Samples $160-967 \mathrm{~A}-1 \mathrm{H}-\mathrm{CC}$ to $2 \mathrm{H}-7,35 \mathrm{~cm}$, are placed into Zone MNN20, whereas Samples 160-967A-2H-CC to 4H-3, $132 \mathrm{~cm}$, contain nannofossils from Zone MNN19f. Samples 160-967A-4H-4, 13 $\mathrm{cm}$, to $5 \mathrm{H}-1,67 \mathrm{~cm}$, contain nannofossils from Zone MNN19e. Zone 
MNN19d is identified from Samples $160-967-5 \mathrm{H}-1,135 \mathrm{~cm}$, to $5 \mathrm{H}-$ 7, $45 \mathrm{~cm}$. Samples 160-967A-5H-CC and 6H-2, $120 \mathrm{~cm}$, contain nannofossil assemblages attributed to Zones MNN19c-b. Samples 160967A-6H-3, $20 \mathrm{~cm}$, to $6 \mathrm{H}-6,130 \mathrm{~cm}$, contain nannofossils from Zones MNN19a-MNN18? and Samples 160-967A-6H-7, $21 \mathrm{~cm}$, to 8 H-6, 55 cm, contain nannofossils from Zone MNN18. Samples 160967A-8H-6, $120 \mathrm{~cm}$, to $9 \mathrm{H}-4,55 \mathrm{~cm}$, contain nannofossils from Zones MNN17-16b. Zone MNN16a is identified from Samples 160967A-9H-4, $130 \mathrm{~cm}$, to $11 \mathrm{H}-6,37 \mathrm{~cm}$. Samples 160-976A-11H-7, 30 $\mathrm{cm}$, to $12 \mathrm{H}-4,71 \mathrm{~cm}$, contain nannofossils belonging to Zones MNN14-15. Samples 160-967A-12H-5, $20 \mathrm{~cm}$, to $12 \mathrm{H}-6,30 \mathrm{~cm}$, contain nannofossils belonging to the Zone MNN13. Sample 160$967 \mathrm{~A}-13 \mathrm{H}-1,77 \mathrm{~cm}$, is the lowermost sample that can be confidently placed into the Pliocene Zone MNN12.

\section{Bachmayerella tenuis and Incertae sedis, forma A}

Incertae sedis, forma A, is generally well preserved and varies from very rare to abundant. Its last occurrence is observed in Sample 160-967A-3H-CC in the lower part of Zone MNN19f.

Bachmayerella tenuis abundance varies from very rare to common, and it is generally well preserved. It last occurs in Sample 160967A-5H-1, 67-70 cm, in the lowermost part of Zone MNN19e (Table 4).

\section{Hole 969A}

Hole 969A is located on the Mediterranean Ridge. Thirteen cores were retrieved with a core recovery of $100 \%$. The APC was used from 0 to $108.3 \mathrm{mbsf}$ ( $135.55 \mathrm{rmcd})$. The sedimentary sequence recovered at this hole consists of Pliocene-Quaternary nannofossil oozes and nannofossil clays, with more than 80 sapropels from the lower Pliocene through the Holocene.

\section{Planktonic Foraminifers}

Pleistocene and Pliocene foraminifers range in abundance from absent to dominant and consist of diversified and generally wellpreserved faunas. The lower part of the section was devoid of planktonic foraminifers, and abundant Cyprideis pannonica (ostracod) were found. The interval spanning the T. truncatulinoides-G. cariacoensis Zones was identified from Samples 160-969A-1H-1, 63-65 $\mathrm{cm}$, to Sample 160-969A-4H-5, 3-5 cm (from 0.65 to $42.03 \mathrm{rmcd}$ ). This extended interval accounts for about one third of the entire sedimentary sequence. Only Sample 160-969A-4H-6, 5-7 cm, was attributed to Zone MP16 (44.60 rmcd). Zone MPI5b is identified from Samples 160-969A-4H-CC to $7 \mathrm{H}-1,121-123 \mathrm{~cm}$ (from 47.78 to 77.03 rmcd). Only Sample 160-969A-7H-2, 116-120 cm (79.34 rmcd), belongs to Zone MPl5a. Sample 160-969A-7H-3, 120-122 $\mathrm{cm}$, is attributed to Zone MPl4b (81.05 rmcd). Zone MPl4a is identified from Samples 160-969A-7H-4, 117-119 cm, to 8H-5, 43-45 cm (from 82.76 to $93.35 \mathrm{rmcd}$ ). Zone MPl3 is recognized from Samples $160-969 \mathrm{~A}-8 \mathrm{H}-\mathrm{CC}$ through $9 \mathrm{H}-\mathrm{CC}$, whereas Zone MPl2 is identified from Samples 160-969A-10H-3, 100-102 cm, through $10 \mathrm{H}-\mathrm{CC}$ (from 97.03 to 109.25 and from 115.64 to $121.23 \mathrm{rmcd}$, respectively). The sedimentary section below is attributed to Zone MPl1 down to Sample 160-969A-11H-CC (from 123.8 to $129.95 \mathrm{rmcd}$ ).

\section{Calcareous Nannofossils}

The base zone (MNN21) was detected in Sample 160-969A-1HCC. Samples 160-969A-2H-1, $70 \mathrm{~cm}$, to $2 \mathrm{H}-3,65 \mathrm{~cm}$, are placed into Zone MNN20. Samples 160-969A-2H-3, $65 \mathrm{~cm}$, to $3 \mathrm{H}-1,66 \mathrm{~cm}$, contain nannofossils from Zone MNN19f. Samples 160-969A-3H-2, $15 \mathrm{~cm}$, to $3 \mathrm{H}-5,31 \mathrm{~cm}$, are attributed to Zone MNN19e. Samples 160-969A-3H-5, $70 \mathrm{~cm}$, through $3 \mathrm{H}-\mathrm{CC}$ contain nannofossils from
Zone MNN19d. Samples 160-969A-4H-1, $76 \mathrm{~cm}$, to $4 \mathrm{H}-2,140 \mathrm{~cm}$, contain nannofossils from Zones MNN19c-b. Nannofossil assemblages in Samples 160-969A-4H-3, $9 \mathrm{~cm}$, to $4 \mathrm{H}-6,5 \mathrm{~cm}$, can be attributed to Zone MNN19a. Samples 160-969A-4H-6, $68 \mathrm{~cm}$, to $6 \mathrm{H}-$ $7,70 \mathrm{~cm}$, are attributed to the interval spanning Zones MNN18-16b. Samples 160-969A-6H-7, $70 \mathrm{~cm}$, to $8 \mathrm{H}-5,120 \mathrm{~cm}$, contain nannofossils belonging to Zone MNN16a. Zones MNN14-15 is identified from Samples 160-969A-8H-6, $120 \mathrm{~cm}$, to $9 \mathrm{H}-2,120 \mathrm{~cm}$. Samples 160-969A-9H-3, $48 \mathrm{~cm}$, through $9 \mathrm{H}-\mathrm{CC}$ contain nannofossils belonging to Zone MNN13, and Samples 160-969A-10H-1, $120 \mathrm{~cm}$, through $11 \mathrm{H}-\mathrm{CC}$ contain nannofossils belonging to Zone MNN12. The sediments below could not be placed into a zone because of a paucity of nannofossils and significant reworking of older taxa.

\section{Bachmayerella tenuis and Incertae sedis, forma A}

Incertae sedis, forma $\mathrm{A}$, is generally well preserved and varies from very rare to abundant. Its LO is observed in Sample 160-969A$3 \mathrm{H}-1,21-22 \mathrm{~cm}$, at $19 \mathrm{rmcd}$ in the lower part of Zone MNN19f, and the first observation lies in Sample 160-969-9H-3, 48-50 cm, at $102.58 \mathrm{rmcd}$. Therefore, Incertae sedis, forma A, is missing in part of Zones MP13 through MP11.

Bachmayerella tenuis abundance varies from absent to common and is generally well preserved. It last occurs in Sample 160-969A$3 \mathrm{H}-5,31-33 \mathrm{~cm}$, in the lowermost part of Zone MNN19e (Table 5).

\section{DISCUSSION Biostratigraphy}

The biostratigraphic resolution of planktonic foraminifers worldwide is usually very low in the Pleistocene. In addition, most of the global markers commonly used are either absent or very rare in the Mediterranean geologic sequences from the Miocene to the Holocene. Although several zonations were developed for only the Mediterranean area (Cita, 1975; Iaccarino, 1985; Sprovieri, 1992, 1993), the Pleistocene remains the most problematic interval for planktonic foraminifer biostratigraphy.

In the Eastern Mediterranean sites, the zonal boundary between the T. truncatulinoides excelsa and G. cariacoensis Zones was never clearly identified because of the scarcity of $T$. truncatulinoides. This species, in fact, occurs very discontinuously, and its occurrence is strongly influenced by environmental factors (Di Stefano and Sprovieri, 1990).

The thickness of the T. truncatulinoides excelsa-G. cariacoensis Zones interval varies from site to site depending on the sedimentation rate. In Holes 965A, 966A, 967A, and 969A, it is about 11, 30, 52, and $42 \mathrm{~m}$ thick, respectively. To improve the biostratigraphic resolution of this extended problematic interval of $1.81 \mathrm{Ma}$, we informally propose an integrated zonal scheme that incorporates planktonic foraminifer, B. tenuis and Incertae sedis, forma A, events. This interval can be divided in three subzones from the bottom to the top as follows:

\section{Subzone A (Bachmayerella tenuis)}

Definition: Interval between the increasing abundance of Neogloboquadrina pachyderma sinistral to the $\mathrm{LO}$ of $B$. tenuis.

Remarks: The planktonic foraminifer assemblages in this subzone are relatively uniform throughout. They consist of Orbulina universa, Globorotalia inflata, Globigerinoides ruber, Globorotalia scitula, Globigerina bulloides, Turborotalita quinqueloba, Globigerinita glutinata, Globigerinita juvenilis, and Neogloboquadrina pachyderma (both dextral and sinistral forms). Rare taxa include Globigerinoides sacculifer, Pulleniatina obliquiloculata, Globigerinoides gomitulus, Globigerinoides pyramidalis, and Globigerinoides conglobatus. Bachmayerella tenuis and Incertae sedis, forma A, characterize the 40 - to $160-\mu \mathrm{m}$-size fraction. 
Table 6. Oxygen and carbon isotopic composition of Globigerinoides obliquus, Oridorsalis stellatus, and Incertae sedis, forma A.

\begin{tabular}{|c|c|c|c|c|c|c|}
\hline \multirow{2}{*}{$\begin{array}{l}\text { Core, section, } \\
\text { interval }(\mathrm{cm})\end{array}$} & \multicolumn{2}{|c|}{$\begin{array}{l}\text { Globigerinoides } \\
\text { obliquus }\end{array}$} & \multicolumn{2}{|c|}{$\begin{array}{c}\text { Oridorsalis } \\
\text { stellatus }\end{array}$} & \multicolumn{2}{|c|}{$\begin{array}{c}\text { Incertae sedis, } \\
\text { forma A }\end{array}$} \\
\hline & $\delta^{13} \mathrm{C}$ & $\delta^{18} \mathrm{O}$ & $\delta^{13} \mathrm{C}$ & $\delta^{18} \mathrm{O}$ & $\delta^{13} \mathrm{C}$ & $\delta^{18} \mathrm{O}$ \\
\hline \multicolumn{7}{|l|}{ 160-965A- } \\
\hline $3 \mathrm{H}-2,7-9$ & 1.856 & 1.38 & -0.714 & 2.286 & -1.007 & 1.485 \\
\hline $3 \mathrm{H}-4,135-137$ & 1.823 & -0.494 & -0.408 & 1.849 & -0.615 & 1.542 \\
\hline $3 \mathrm{H}-5,29-31$ & 1.822 & -0.264 & -0.703 & 1.79 & -0.469 & 1.709 \\
\hline $3 \mathrm{H}-5,35-37$ & 1.918 & -1.031 & -0.984 & 1.865 & -1.291 & 1.218 \\
\hline \multicolumn{7}{|l|}{ 160-967A- } \\
\hline $11 \mathrm{H}-2,71-73$ & 1.172 & -0.463 & -0.915 & 1.044 & -0.32 & 0.969 \\
\hline $11 \mathrm{H}-3,87-89$ & 1.377 & -0.271 & -0.648 & 1.523 & -0.217 & 1.358 \\
\hline $12 \mathrm{H}-1,26-28$ & 1.505 & -0.425 & -0.965 & 0.495 & -0.183 & 1.608 \\
\hline $12 \mathrm{H}-5,38-40$ & 1.285 & -0.404 & -0.517 & 1.222 & 0.406 & 1.761 \\
\hline
\end{tabular}

Note: All data expressed against the PDB standard.

\section{Subzone B (Incertae sedis, forma A)}

Definition: Interval between the LO of B. tenuis and the LO of Incertae sedis, forma A.

Remarks: No significant changes occur in planktonic foraminifer assemblages in this subzone. Only exception is the presence of Incertae sedis, forma $\mathrm{A}$, in absence of $B$. tenuis in the 40- to $160-\mu \mathrm{m}$-size fraction.

Subzone C (T. truncatulinoides excelsa)

Definition: Interval between the LO of Incertae sedis, forma A, and the modern seafloor.

Remarks: The planktonic foraminifer assemblages are generally uniform in this subzone. Variations in relative abundance occur during climatic changes.

\section{Stable isotopes}

The isotopic composition of the marine biogenic carbonate (e.g., in shells of several species of planktonic and benthic foraminifers) is a function of the $\delta^{18} \mathrm{O}$ and $\delta^{13} \mathrm{C}$. The $\delta^{18} \mathrm{O}$ value reflects mainly the temperature and the salinity of the water in which the foraminifers lived and in which shells were calcified, whereas the $\delta^{13} \mathrm{C}$ is mostly related to the primary production (Shackleton, 1967; Douglas and Savin, 1973; Bender and Keigwin, 1979). Therefore, the stable isotope composition of these marine fossils has been used for paleoceanographic and paleoclimatic reconstructions since the pioneering study of Emiliani (1955).

On the contrary, the study of the isotopic composition of marine microflora is relatively newer. Previous studies revealed that the calcareous nannoplankton may also be a major tool in both paleoceanographic and paleoclimatic reconstruction (Anderson and Arthur 1983; Steinmetz, 1994). However, the vital effects during coccolith formation play a very important role in the isotope fractionation (Anderson and Steinmetz, 1983; Steinmetz and Anderson, 1984; Steinmetz 1994). Dudley et al. (1986) demonstrated that the biological fractionation is not consistent for all the species, and it may be responsible for an isotopic composition lighter or heavier with respect to the $\mathrm{CaCO}_{3}$ precipitated at the equilibrium.

Another group of marine microfossils, Bolboforma (recently studied by Spiegler and Erlenkeuser [in press]), revealed that the carbon and oxygen isotopic composition of the calcareous tests of these fossils is remarkably heavier than that of coeval benthic and planktonic foraminifers, and may reflect the isotopic composition of the bottom water during the cold autumn-winter periods.

Very little is currently known on the isotopic composition of dinoflagellates. The study of the cysts of living dinoflagellates is also

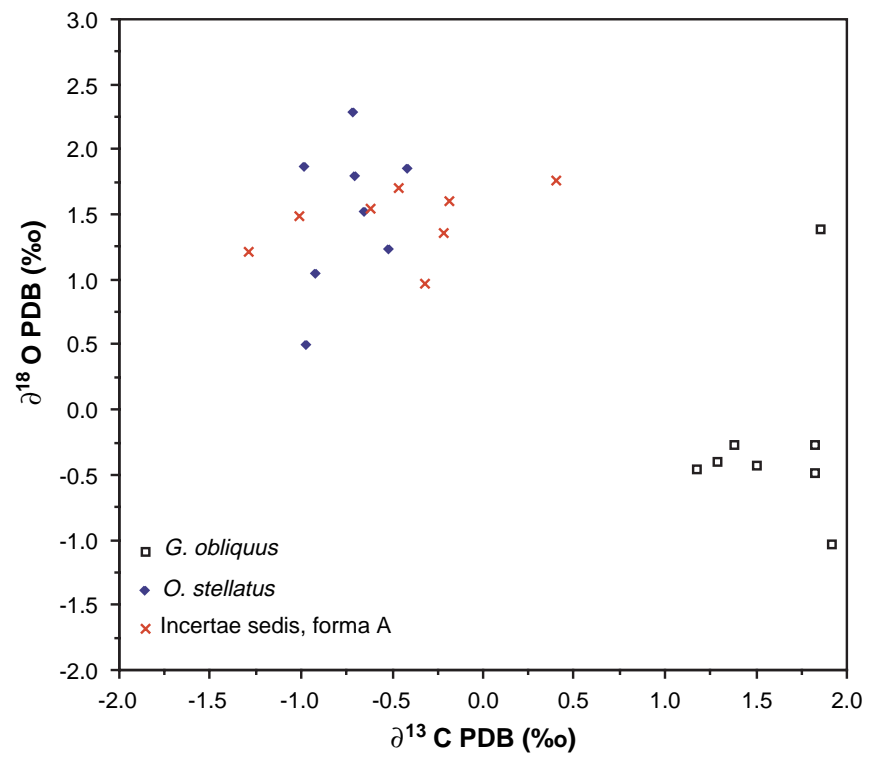

Figure 3. Values of $\delta^{18} \mathrm{O}$ plotted vs. values of $\delta^{13} \mathrm{C}$ of Globigerinoides obliquus, Oridorsalis stellatus, and Incertae sedis, forma A.

relatively new. According to Dale (1983) and Sandgren (1983), dinoflagellates produce benthic cysts, which may be interpreted as a survival strategy allowing them to survive under conditions adverse for the motile stage. The early stage of cyst formation begins within the photic zone, then cysts quickly sink in the water column to concentrate in the unconsolidated or floculative upper layer of the bottom sediment (Dale, 1983). In comparing the isotopic composition of the planktonic foraminifer $G$. obliquus, the benthic foraminifer $O$. stellatus, and Incertae sedis, forma A (Fig. 3), we find evidence that the isotopic composition of the latter more closely resembles that of the benthic rather than that of the planktonic foraminifer.

If, as a working hypothesis, we assume that Incertae sedis, forma A, belongs to the calcdinocyst group, this suggests that these forms may have completed the calcification of the test close to the seafloor. However, no direct observations of living form are available to prove or disprove this hypothesis.

Finally, the ongoing studies on Incertae sedis, forma A, will hopefully clarify the nature of the calcareous infilling in the texts and its possible influence on the isotopic composition.

\section{SUMMARY AND CONCLUSIONS}

Bachmayerella tenuis and Incertae sedis, forma A, occur in the Pliocene-Pleistocene sediments from the Eastern Mediterranean. A new form is informally described (Incertae sedis, forma A). It may belong to the calcdinocysts group, but further light optical studies on the wall texture are needed.

The range of B. tenuis and Incertae sedis, forma A, allow a remarkable improvement of the stratigraphic resolution of the Pleistocene interval of $G$. cariacoensis-T. truncatulinoides excelsa. An informal zonation incorporating planktonic foraminifers and Bachmayerella tenuis and Incertae sedis, forma A, events is proposed.

The isotopic composition of the test of Incertae sedis, forma A, is similar to that of the benthic foraminifer $O$. stellatus. This may indicate that Incertae sedis, forma A, possibly completed the calcification of the test close to the seafloor. 
Further taxonomic and isotopic studies are underway. They may incorporate also the fraction smaller than $40 \mu \mathrm{m}$, because most calcdinocysts occur in the size range of $15-90 \mu \mathrm{m}$.

\section{ACKNOWLEDGMENTS}

Thanks to ODP for inviting the senior author aboard on Leg 160 and providing the large number of samples. Thanks especially to Tatsuiko Sakamoto, who calculated with so much patience the rmcd of the Leg 160 Sites. The paper was helpfully reviewed by Ch. Betzler and an anonymous reviewer. Financial support was given to Dorothee Spiegler by the Deutsche Forschungsgemeinschaft Bonn and to Silvia Spezzaferri from the European Science Foundation and Consiglio Nazionale Ricerche (CNR) of Italy.

\section{REFERENCES}

Anderson, T.F. and Arthur, M.A., 1983. Stable isotopes of oxygen and carbon and their applications to sedimentologic and paleoenvironmental problems. In Arthur, M.A., Anderson, T.F., Kaplan, I.F., Veizer, J., and Land, L.S. (Eds.), Stable Isotopes in Sedimentary Geology. SEPM Short Course, 10.

Anderson, T.F., and Steinmetz, J.C., 1983. Stable isotopes in calcareous nannofossils: potential application to deep-sea paleonvironmental reconstructions during the Quaternary. In Meulenkamp, J.E. (Ed.), Reconstruction of Marine Paleoenvironments. Utrecht Micropaleontol. Bull., 30:189-204.

Bender, M.L., and Keigwin, L.D., Jr., 1979. Speculations about the Upper Miocene change in abyssal Pacific dissolved bicarbonate $\delta^{13} \mathrm{C}$. Earth Planet. Sci. Lett., 45:383-393.

Cande, S.C., and Kent, D.V., 1995. Revised calibration of the geomagnetic polarity timescale for the Late Cretaceous and Cenozoic. J. Geophys. Res., 100:6093-6095

Cita, M.B., 1975. Studi sul Pliocene e gli strati di passaggio dal Miocene al Pliocene, VII. Planktonic foraminiferal biozonation of the Mediterranean Pliocene deep sea record: a revision. Riv. Ital. Paleontol. Stratigr., 81:527-544.

Craig, H., 1957. Isotopic standards for carbon and oxygen and correction factors for mass-spectrometric analysis of carbon dioxide. Geochim. Cosmochim. Acta, 12:133-149.

Dale, B., 1983. Dinoflagellate resting cysts: "benthic plankton." In Frixwell, G.A. (Ed.), Survival Strategies of the Algae: Cambridge (Cambridge Univ. Press), 69-136.

Di Stefano, E., and Sprovieri, R., 1990. Calcareous plankton biostratigraphy of ODP Leg 107 Site 651, uppermost Pliocene-lowermost Pleistocene. Mem. Soc. Geol. Ital., 44:157-165.

Douglas, R.G., and Savin, S.M., 1973. Oxygen and carbon isotope analyses of Cretaceous and Tertiary foraminifer from central north Pacific. In Winterer, E.L., Ewing, J.I., et. al., Init. Repts. DSDP, 17: Washington (U.S. Govt. Print. Office), 591-606.

Dudley, W.C., Blackwelder, P.L., Brand, L.E., and Duplessy, J.C., 1986. Stable isotopic composition of coccoliths. Mar. Micropaleontol., 10:1-8.

Emeis, K.-C., Robertson, A.H.F., Richter, C., et al., 1996. Proc. ODP, Init. Repts., 160: College Station, TX (Ocean Drilling Program).

Emiliani, C., 1955. Pleistocene temperatures. J. Geol., 63:538-578.

Hildebrand-Habel, T., and Willems, H., 1996. Proposed research on Mesozoic and Cenozoic calcareous dinoflagellates cysts of the South Atlantic
Ocean. Terra Nostra, First EuroColloquium of the Ocean Drilling Program, 49-50.

Hsü, K.J., Montadert L., et al., 1978. Init. Repts. DSDP, 42A: Washington (US Govt. Printing Office).

Iaccarino, S., 1985. Mediterranean Miocene and Pliocene planktic foraminifera. In Bolli, H.M., Saunders, J.B., and Perch-Nielsen, K. (Eds.), Plankton Stratigraphy: Cambridge (Cambridge Univ. Press), 283-314.

Kastens, K.A., Mascle, J., Auroux, C., et al., 1987. Proc. ODP, Init. Repts., 107: College Station, TX (Ocean Drilling Program).

Keupp, H., 1990. Fossil calcareous dinoflagellate cysts. In Riding, R. (Ed.) Calcareous Algae and Stromatolites: Berlin (Springer), 267-286.

Kohring, R., 1993. Kalkdinoflagellaten aus dem Mittel- und Obereozaen von Juetland und dem Priser Becken im Vergleich mit anderen TertiäerVorkommen. Berliner Geowiss. Abh., Reihe E, Band 6.

Rio, D., Raffi, I., and Villa, G., 1990. Pliocene-Pleistocene calcareous nannofossil distribution patterns in the Western Mediterranean. In Kastens, K.A., Mascle, J., et al., Proc. ODP, Sci. Results, 107: College Station, TX (Ocean Drilling Program), 513-533.

Rögl, F., and Franz, H.E., 1979. Bachmayerella: ein neues problematisches Mikrofossil aus dem marinen Mittelmiozän von Walbersdorf, Burgenland. Ann. Naturhist. Mus. Wien, 82:83-96.

Ryan, W.B.F., Hsü, K.J., et al., 1973. Init. Repts. DSDP, 13 (Pts. 1 and 2): Washington (U.S. Govt. Printing Office).

Sandgren, C.D., 1983. Survival strategies of chrysophycean flagellates: reproduction and the formation of resistant resting cysts. In Frixwell, G.A. (Ed.), Survival Strategies of the Algae: Cambridge (Cambridge Univ. Press), 24-48.

Shackleton, N., 1967. Oxygen isotope analyses and Pleistocene temperatures re-assessed. Nature, 215:15-17.

Shackleton, N.J., Berger, A., and Peltier, W.A., 1990. An alternative astronomical calibration of the lower Pleistocene timescale based on ODP Site 677. Trans. R. Soc. Edinburgh: Earth Sci., 81:251-261.

Spiegler, D., and Erlenkeuser, H., in press. $\delta 180$ und $\delta 13 \mathrm{C}$ in Foraminiferen und Bolboformen aus dem Miozän der Forschungsbohrung Nieder Ochtenhausen (Niedersachsen, Nord-Deutschland). Geol. Jahrb.

Sprovieri, R., 1992. Mediterranean Pliocene biochronology: a high resolution record based on quantitative planktonic foraminifera distribution. Riv. Ital. Paleontol. Stratigr., 98:61-100.

1993. Pliocene-early Pleistocene astronomically forced planktonic foraminifera abundance fluctuations and chronology of Mediterranean calcareous plankton bio-events. Riv. Ital. Paleontol. Stratigr., 99:371-414.

Steinmetz, J.C., 1994. Stable isotopes in modern coccolithophores. In Winter, A., and Siesser, W. (Eds.), Coccolithophores: Cambridge (Cambridge Univ. Press).

Steinmetz, J.C., and Anderson, T.F., 1984. The significance of isotopic and paleontologic results on Quaternary calcareous nannofossil assemblages from Caribbean Core P6304-4. Mar. Micropaleontol., 8:403-424.

Szczechura, J., 1986. Microproblematics Bolboforma and Bachmayerella from the Middle Miocene of Central Paratethys. Acta Paleontol. Polonica, 31:213-228.

Date of initial receipt: 15 January 1997

Date of acceptance: 9 July 1997

Ms 160SR-025 


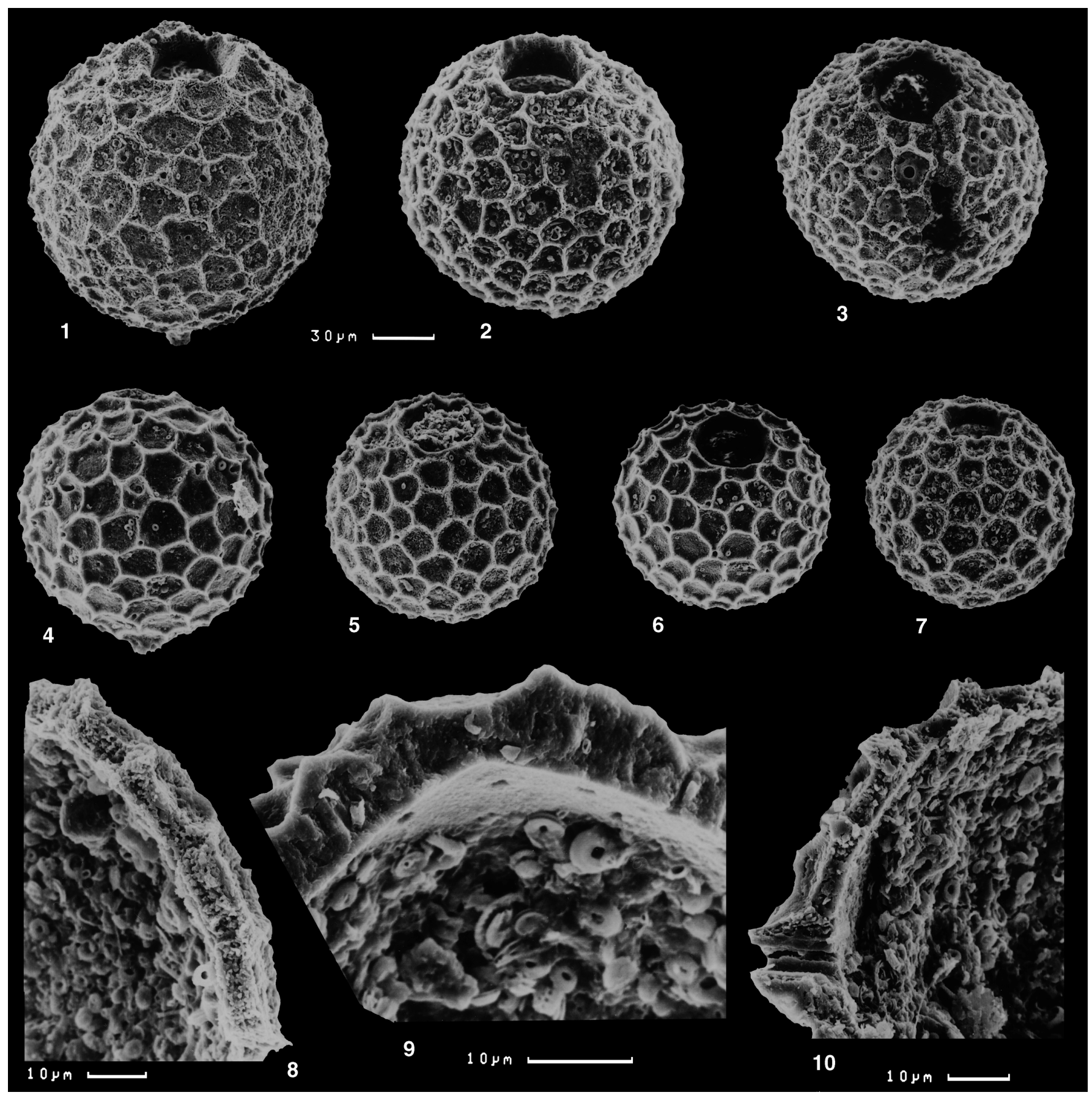

Plate 1. Bachmayerella tenuis from the Eastern Mediterranean. 1-3. Bachmayerella cf. tenuis Rögl and Franz. 4-7. Bachmayerella tenuis Rögl and Franz. 8-10. Bachmayerella tenuis Rögl and Franz. Details of the wall texture. In Figure 8, note the elongated calcite microcrystals, oriented perpendicular to the surface of the cyst. All figures from Sample 160-967A-11H-1, 73-75 cm. 


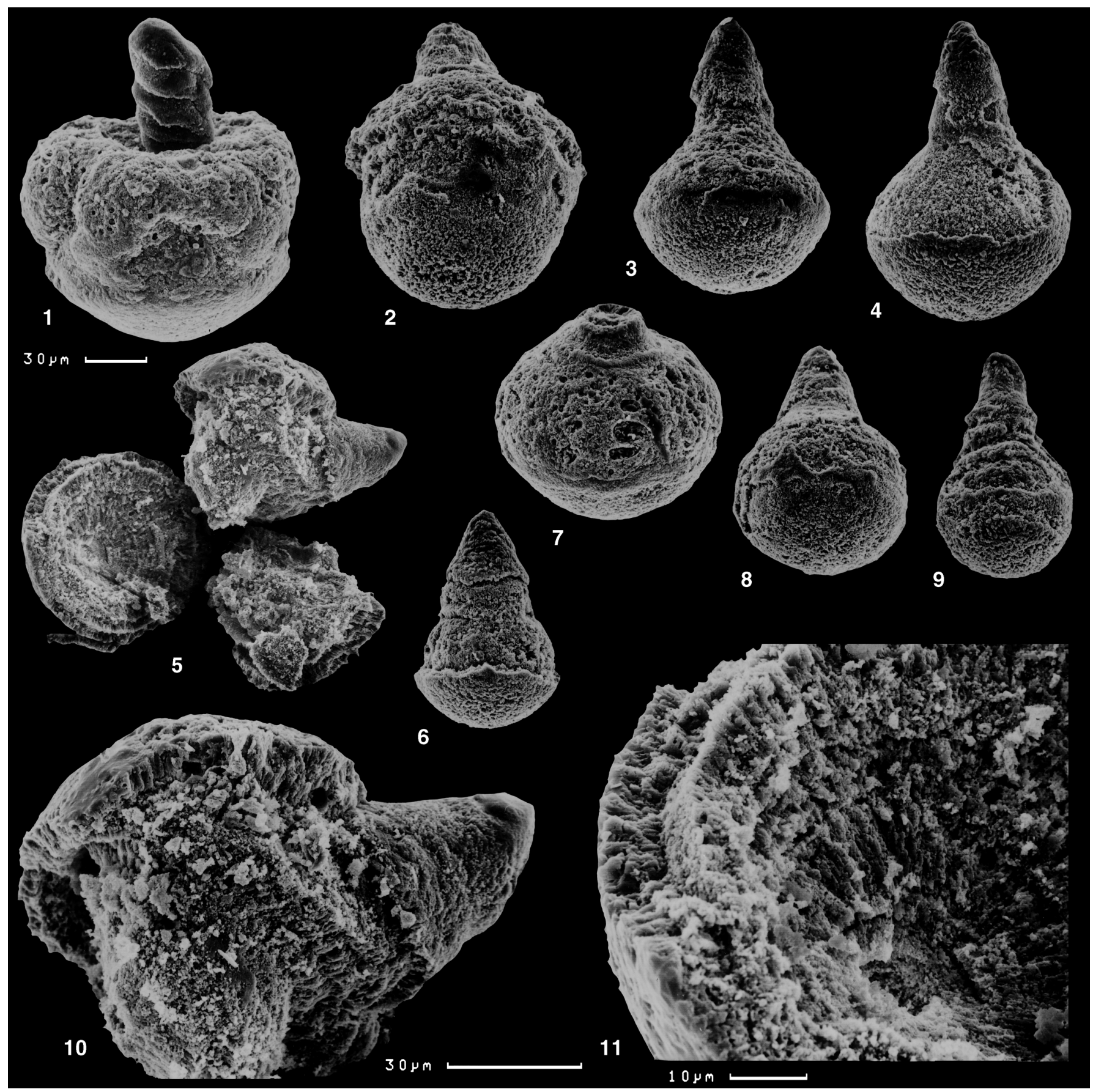

Plate 2. Incertae sedis, forma A, from the Eastern Mediterranean. 1-9. Incertae sedis, forma A, Sample 160-967A-11H-1, $73-75 \mathrm{~cm}$. In Figures 3 and 4 , note the remains of a possible paracingulum. Figure 5 shows a broken specimen. In Figure 7, note the possible apical archaeophyle. 10-11. Details of Figure 5. Note the probably single-layered wall texture that may consist of elongated calcite microcrystals, oriented perpendicular to surface of the cyst. 